\title{
Tidayu ethnic harmonization in semiotic review of face negotiations conflict styles
}

\author{
${ }^{1}$ Rustono Farady Marta*, ${ }^{1}$ Merry, ${ }^{1}$ Febryan Kurniawan, ${ }^{2}$ Herda \\ Seftira, ${ }^{3}$ Mercedes Amanda \\ ${ }^{1}$ Master's Degree of Communication Science Department, Post-Graduate Studies, \\ Universitas Bunda Mulia, Jakarta, Indonesia \\ ${ }^{2}$ Graduate School of Cinematic Contents, Dankook University, Republic of Korea \\ ${ }^{3}$ Graduate School of Journalism and Communication, Huaqiao University, China
}

*Corresponding Author

Email: frad_sby@yahoo.com

Received:

25 December 2020
Revised:

18 June 2021
Accepted:

01 July 2021
Published:

31 August 2021

\begin{abstract}
The various ethnic groups with distinctive characteristics of each culture in Indonesia have consequences for potential conflicts among them. Tidayu ethnicity is a complete reflection of the interwoven between the three dominant ethnicities in the West Kalimantan region, including: Tionghoa, Dayak, and Malay. This study aims to reveal the meaning of the various signs displayed by the style of inter-ethnic conflict in a video show entitled "Bhinneka Tunggal Ika" with a review of the face negotiation theory proposed by Stella Ting-Toomey. The Thomas Albert Sebeok's Six Sign Semiotics method is used to examine the audio-visual data. The results of the research show that there is a harmonization of signs of various styles of conflict between ethnic groups, so that it becomes a great strength for the Indonesian Nation and State in particular to increase its social solidarity.
\end{abstract}

Keywords: Tidayu ethnicity; Conflict Style; Hamonization; Sebeok Semiotics; Face Negotiation Theory

\section{INTRODUCTION}

Indonesia is a multicultural country with more than 1331 ethnic categories (Moningka et al., 2020). Cultural diversity can be the uniqueness of a nation, but it can also become an inevitable axis of social conflict. However, social conflict can be prevented if each social and cultural group has an attitude of tolerance in intercultural communication to build harmony in differences. One of them is Ethnic Tidayu as an acronym for the three majority ethnic groups in West Kalimantan, consisting of Tionghoa, Dayak, and Melayu ethnic who have lived side by side for a long time.

West Kalimantan is one of the areas that has great potential for ethnic conflict (Suprapto, 2018). Inter-ethnic friction in West Kalimantan began in 1962-1999 and has led to 14 ethnic conflicts including conflict between Dayaks and ethnic Tionghoa in 1967, conflict between Melayu ethnic and 
ethnic Madurese in 1998 and 1999, and conflict between ethnic Dayaks and ethnic groups. Madura eleven times in 1962, 1963, 1968, 1972, 1976, 1977, 1979, 1983, 1993, 1994, 1996, 1997. From a historical perspective, it appears that this area is prone to horizontal conflicts. Now, precisely the three tribes can live in harmony in intercultural communication, it is proven that Singkawang City as one of the cities in West Kalimantan has been named the Most Tolerant City in 2018 by the Setara Institute (Merry \& Rianto, 2020).

Such a contrasting condition from the past with the current situation is certainly interesting to study. Coexist in cultural differences beyond a certain time to achieve harmony between cultures. The process of intercultural communication goes hand in hand with the face and identity of each culture in order to maintain intercultural harmony so that conflicts can be prevented and managed properly.

In previous research, the focus of research related to the Tidayu ethnicity tended to raise social integration between ethnic groups and there was no literature review that discussed the meaning of integration between ethnic groups that was studied through audio-visual media. Therefore, this research sees this opportunity to examine the meaning of integration between ethnic groups through audio-visual media in the form of a video entitled "Bhinneka Tunggal Ika". Penelitian ini ditelaah dengan analisa gaya konflik menurut Stella Ting-Toomey melalui berbagai tanda yang mencerminkan negosiasi wajah lintas etnis dan juga gaya konflik antar wajah antar etnik Tionghoa, Dayak dan Melayu. This research is analyzed by analyzing the conflict style according to Stella Ting-Toomey through various signs that reflect the face negotiations across ethnicities and also the style of conflict between faces between ethnic Tionghoa, Dayak and Malay.

\section{Cross-ethnic face negotiation}

Face Negotiation Theory is used in various intercultural communication literature which explains that the face is a conflict style management mechanism between different cultures. Faces represent feelings that are claimed as positive social values and facework is an individual strategy undertaken to maintain, support or challenge the faces of others (Fletcher et al., 2014).

This theory was developed by Stella Ting Toomey (1988) with 32 propositions that focus on the comparison of conflict behavior between cultural variables such as individualistic-collectivistic and conflict styles. Ting Toomey explained that faces can be negotiated when interacting with other people, especially in terms of culture, for example when communicating between cultures between different cultural groups. Ting-Toomey diversifies face negotiation theory into 3 (three) basic foundations, namely understanding the importance of faces in an ethnic group and the ability to understand differences and know what is important to others (knowledge), the ability to realize a cultural identity and readiness to change new perspectives (mindfulness). ), as well as the ability to negotiate faces through observation, empathy, understanding non-verbal language, and so on (Hidayat, 2014). 


\section{Conflict Style Between Faces}

Ting-Toomey in Walsh et al explained that when facing a conflict there are 5 (five) kinds of conflict styles, namely dominating, avoiding, integrating, compromising, and obliging. Dominating style tries to put pressure on the other person to threaten their face in the hope of suppressing their confidence. The second style of conflict is avoiding, this style is more directed at avoiding conflict to save faces from the interlocutor and tends to choose to maintain good relationships in order to create harmony between the two parties. While the third style of conflict, Integrating thinks more about the faces of the two parties by making compromises or discussing when faced with conflicts. (Walsh et al., 2003). In a compromising conflict style, a condition occurs where both parties think about each other's faces and in the last conflict style, obliging is the opposite of dominating where in this fifth conflict style is more concerned with the face of the interlocutor than his own face (Oetzel \& TingToomey, 2003).

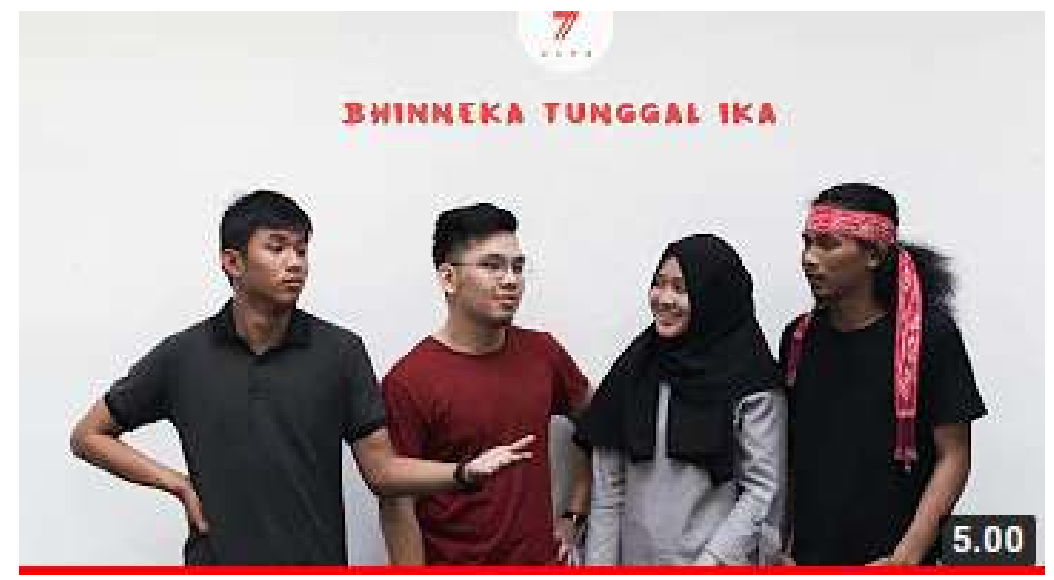

Figure 1. Youtube video entitled "Bhinneka Tunggal Ika" Source: https://www.youtube.com/watch?v=te3BS-CbWwU

Considering the dynamics of the conflict style can be traced through various signs, each sign shown by the characters having a dialogue in an audio-visual presentation is interpreted to find the essential communication behind each of his words. The broadcast in question has been released since May 29, 2017 on Youtube channel with the title "Bhinneka Tunggal Ika", can be seen in Figure 1. The choice of the object of this research is based on such contrasting differences (as explained in the introduction), along with the historical journey which is full of traces of horizontal conflicts with the current situation which is so harmonious.

There is a young man on the far left wearing a green polo-shirt representing ethnic Malay, then next to him is wearing glasses with The red tshirt is a characteristic of Tionghoa ethnicity, then in the middle number three from the left wearing a hijab acts as a narrator, and at the far right with a black t-shirt and a patterned headband that clearly reflects Dayak ethnicity. This short 4-minute 59-second broadcast specifically tells the style of conflict between three ethnic groups in West Kalimantan, namely the Tionghoa, the Dayak and the Melayu. 


\section{METHOD}

This research uses an interpretive paradigm to see facts as something unique and has its own meaning (Muslim, 2016) and this paradigm was chosen so that the researcher could provide a description of the unit of analysis selected in this study. With a qualitative approach, this study tries to interpret the object of research under study using the six-sign semiotic analysis method from Thomas Albert Sebeok.

The six signs according to Thomas A. Sebeok are signal, simpton, icon, index, symbol and name. A sign can be said to be a signal when an existing sign mechanically or conventionally triggers some action in the first party. Meanwhile, simpton itself is a compulsive sign, automatic, not arbitrary so that the markers are combined with those marked by natural linking. The third sign of 6 is an icon, this is said to be a sign if there is a topological similarity between the marker and its denotata. The next sign is an index, where a sign can be said to be indexic as long as it is adjacent to what it signifies. Signs without proximity, but only with the conventional relationship between the signifier and its denotata and with the deliberate class for its marking are hereinafter referred to as symbols. while the last sign is a name, this is a sign that has an extensional class for designation.

Semiotics itself is used to examine the signs used in finding meaning and ways in the order of human life (Christina, 2016). The video selection entitled "Bhinneka Tunggal Ika" with a duration of 4 minutes 59 seconds because it represents the lives of 3 (three) ethnic groups in West Kalimantan such as Singkawang City and Pontianak City who live in harmony with cultural plurality and show the style of conflict and faces shown by each. each ethnic group in their daily lives to save the faces of each ethnic group or even protect the faces of others.

This research was also reviewed using the Face Negotiation Theory by Stella Ting-Toomey with the classification of interpersonal conflict styles into 5 (five) types, including: Avoiding (AV), Dominating (DO), Integrating (IN), Obliging (OB), and Compromising (CO) (Moriizumi \& Takai, 2013).

\section{RESULTS AND DISCUSSION}

Even though there are different ethnicities, races, languages, religions, cultures, Indonesian people are required to live in a pluralistic harmony in accordance with the country's motto, namely Bhinneka Tunggal Ika. The importance of maintaining harmony between ethnic groups so that people can live in harmony side by side with one another. The differences between the Tidayu ethnic groups are presented in audio-visual media in the form of diversified videos based on 6 (six) signs according to Thomas A. Sebeok. The first study will start from the meaning of the signal. 
EduLite Journal of English Education, Literature, and Culture

Vol. 6, No. 2, August 2021, pp. 369-382

E-ISSN: 2528-4479, P-ISSN: 2477-5304

http://jurnal.unissula.ac.id/index.php/edulite DOI: http://dx.doi.org/10.30659/e.6.2.369-382

\begin{tabular}{ccl}
\hline & Table 1. Meaning of conflict style in video as Signal \\
\hline Video Duration & Conflict Style & \multicolumn{1}{c}{ Scenes } \\
\hline $01.19-01.25$ & DO & $\begin{array}{l}2 \text { (two) men speak using accents from ethnic Tionghoa } \\
\text { and ethnic Malay. }\end{array}$ \\
\hline $01.26-01.38$ & DO & $\begin{array}{l}\text { The position of the body of an ethnic Malay man shows a } \\
\text { sense of confidence that his statement is correct } \\
\text { accompanied by a dominant tone of tone (nonverbal } \\
\text { communication). }\end{array}$ \\
\hline $01.39-02.11$ & AV \& DO & $\begin{array}{l}\text { The ethnic Malay men still seem to dominate, but the } \\
\text { ethnic Tionghoa men seem to be avoiding by showing } \\
\text { nonverbal communication in the form of body movements } \\
\text { trying to look away, so that the ethnic Malay men change } \\
\text { the conversation by calling a woman to listen to who is } \\
\text { right and wrong between them. }\end{array}$ \\
\hline $02.11-02.50$ & DO & $\begin{array}{l}\text { The two men defend each other's arguments and don't } \\
\text { want to be outdone by each other's ethnic foods. }\end{array}$ \\
\hline $02.51-03.28$ & DO & $\begin{array}{l}\text { The man who just arrived wearing a red headband } \\
\text { accessory is a characteristic of the Dayak ethnic group. }\end{array}$ \\
\hline $03.44-04.22$ & DO \& IN & $\begin{array}{l}\text { The Dayak ethnic men were provoked by emotions } \\
\text { because the ethnic Tionghoa men began to raise their } \\
\text { tones and suddenly stood up. }\end{array}$ \\
\hline $\begin{array}{l}\text { The meaning and ways of how the 3 (three) ethnic groups } \\
\text { respond to Bhinneka Tunggal Ika in differences. }\end{array}$
\end{tabular}

Table 1 describes how verbal and nonverbal communication is shown and can be observed in the video "Bhinneka Tunggal Ika" by three characters, each of which represents the character and style of conflict from ethnic Tionghoa, ethnic Dayaks and Melayu ethnic in a 4 minute 59 second video. this.

Signals are signals that mechanically or conventionally trigger reactions from the receiver. From this video, there are several signals that can be seen directly by each ethnic group. In the duration of $01.19-01.25$, it can be seen that the difference in language from the speaking accent and the more dominant tone of tone is shown by ethnic Malay men. This scene represents the nature of ethnic Malay which has a conflict style of domination over other cultures. Not only from the accent and intonation of the dominating tone, but the ethnic Malay man in the video also shows his self-confidence by standing while rejecting his waist in front of the ethnic Tionghoa man. It can be seen that the ethnic Tionghoa men show a conflict style avoiding at $01.26-01.38$ minutes by not responding to what the ethnic Malay men say or can be said to save the faces of others so that the ethnic Malay men do not feel humiliated.

At 01.39 - 02.11 the ethnic Malay man was still trying to win the argument but finally he called a woman to hear who was right and wrong between the two men. The argument continues between the two ethnic groups with conflict styles dominating each other until the minute $02.51-03.28$ when a man wearing a red headband comes in the middle of their argument. The headband of this man clearly shows that he is of Dayak ethnicity. It can be seen that Dayak ethnic men are provoked by emotions when ethnic Tionghoa men stand up and raise their tone of speech, Dayak ethnic men show a dominating conflict style and do not want to be outdone by 2 (two) other ethnic groups.

At the end of the video, a woman intervenes the conflict between the three ethnic groups which is getting more heated by carrying the message 
"Bhinneka Tunggal Ika" which then shows the style of integrating conflict by the three ethnic groups which finally integrates so that the conflict can be prevented and not prolonged.

Table 2. The meaning of the conflict style in the video as Simpton

\begin{tabular}{|c|c|c|}
\hline Video Duration & Conflict Style & Scenes \\
\hline $01.19-01.38$ & DO & $\begin{array}{l}\text { The statement of the Tionghoa ethnic man that coffee can } \\
\text { give a sense of enthusiasm and the statement of the ethnic } \\
\text { Malay man that drinking ice milk in the afternoon is } \\
\text { fresher. }\end{array}$ \\
\hline $01.39-02.50$ & AV \& DO & $\begin{array}{l}\text { The statement of the Tionghoa man that coffee can give } \\
\text { taste. The Tionghoa man shook his head as a sign of } \\
\text { avoiding and not wanting to raise problems by trying to } \\
\text { compromise. The ethnic Malay man said that bingke is the } \\
\text { most famous food in the area and has been typical of } \\
\text { Melayu ethnic since the city of Pontianak was founded. This } \\
\text { attitude shows ethnocentrism towards other cultures. The } \\
\text { enthusiasm and statements of ethnic Malay men that } \\
\text { drinking ice milk in the afternoon is fresher. }\end{array}$ \\
\hline $02.51-03.28$ & DO & $\begin{array}{l}\text { An ethnic Dayak man stomps the palm wine bottle loudly, } \\
\text { indicating his disapproval that chai kwe and bingke are } \\
\text { typical foods in the area. }\end{array}$ \\
\hline $03.29-03.43$ & DO & $\begin{array}{l}\text { The ethnic Malay man did not accept the high tone of the } \\
\text { Tionghoa man, he stood up and pointed his finger at the } \\
\text { man in red so that the Dayak ethnic man also stood up. }\end{array}$ \\
\hline $03.44-04.22$ & DO \& IN & $\begin{array}{l}\text { The woman (narrator) intervenes in the ongoing conflict by } \\
\text { carrying the message "Bhinneka Tunggal Ika" emphasizing } \\
\text { that differences are not walls of separation and distance but } \\
\text { differences are the power that unites them. The three } \\
\text { ethnicities finally integrated and the story ended. }\end{array}$ \\
\hline
\end{tabular}

Table 2 illustrates how the message implied from conversations in video between ethnic groups through verbal and non-verbal communication where the three ethnic groups argue with each other and maintain their respective faces and cultural identities by favoring their respective cultures in resolving conflicts. From this section we can also see how the conflict styles shown by each culture in maintaining their respective faces and attitudes in resolving conflicts.

In the minutes $01.19-01.25$ an Tionghoa ethnic man said that coffee can give a feeling of enthusiasm, but an ethnic Malay man argued that ice milk in the afternoon was more refreshing. Coffee is an everyday drink that is generally brewed with hot water. Tionghoa people or Chinese have liked hot water since the 20th century as in Kompas.com (Arnani, 2020) that since the beginning of the 20th century, there have been public health campaigns that encourage the consumption of warm water to keep the body warm and it is believed to kill most of the harmful bacteria. On the other hand, hot water is also believed to nourish the yang in the body and achieve a balance between yin and yang.

At $01.39-02.50$ the Tionghoa ethnic man shook his head when the Malay ethnic man said that bingke is the most famous food in the area and has been around since Pontianak City was founded. Ethnic Malay men show an attitude of ethnocentrism towards other cultures. The Tionghoa ethnic man shook his head showing the conflict style of avoiding and not wanting to 
escalate the problem by trying to compromise in order to save his own face as well as that of the Melayu ethnic.

Ethnocentrism is an assumption that the culture that is owned is the most correct, the best compared to other cultures. So that whatever is done will be seen from the perspective of their own ethnicity. The emergence of ethnocentrism can be caused by differences in geographical location, physical differences, differences in social status, differences in norms and customs, or differences in beliefs (Sari \& Samsuri, 2020).

At 02.51 - 03.28 minutes, an ethnic Dayak man stomped a bottle of tuak loudly to show his disapproval that chai kwe and bingke are typical foods in the area. The argument continued until the minute $03.29-03.43$ where the ethnic Malay man did not accept the high tone of the Tionghoa man, he then stood up and pointed his finger at the ethnic Tionghoa man so that the Dayak ethnic man also stood up. In this scene, the three ethnic groups show a conflict style of domination over other cultures and do not want to give in so that each shows the identity and face of each culture by giving priority to the typical food in their respective areas. So that it can be seen that each ethnicity shows a face that challenges each other's faces.

Finally, at the end of the video at 03.44 - 04.22 minutes, the woman (the narrator) breaks up the ongoing conflict by emphasizing that differences are not walls of separation and distance, but differences are the power that unites them. The three ethnic groups then stopped arguing. West Kalimantan is a conflict-prone area, but people live in a plurality and accept differences with an attitude of tolerance and tolerance so that they can unite in harmony.

Table 3. Meaning of conflict style in video as Index

\begin{tabular}{ccl}
\hline Video Duration & Conflict Style & $\begin{array}{l}\text { Ethnic Tionghoa and Malay have lived side by side for a } \\
\text { long time, seen in several ways such as the mixing of the } \\
\text { bride's clothes in a Bangka Malay ethnic wedding that uses } \\
\text { red and gold colors and a number of Bangka culinary } \\
\text { delights such as sweet martabak that have been around for } \\
\text { a long time in people's daily lives. }\end{array}$ \\
\hline $01.19-02.50$ & AV \& DO & $\begin{array}{l}\text { The Dayak ethnic group is believed to be the indigenous } \\
\text { ethnic group who inhabits the island of Borneo }\end{array}$ \\
\hline $03.51-03.28$ & DO & AV, DO, \& \\
IN & $\begin{array}{l}\text { The Dayak and Malay ethnicities are the two dominant } \\
\text { ethnicities with religion as a dividing line. }\end{array}$ \\
\hline
\end{tabular}

Table 3 illustrates how the three ethnic groups have lived side by side with each other for a long time to show the characteristics of each culture. In the delivery process, ethnic Malay men tend to be more dominant than ethnic Tionghoa men. Besides, it is also stated that the choice of belief, in this case religion, is one of the points of difference between Dayak ethnicity and ethnic Malay. Ethnic Tionghoa and Melayu ethnic have long lived side by side, seen in several ways such as the mixing of the bride's clothes in a Bangka Malay ethnic wedding that uses red and gold colors and a number of Bangka culinary delights such as sweet martabak that have been around for a long time in people's daily lives. This is reinforced by the research of Sya et al. (2019) which states that the life of these two ethnic groups has started since Tionghoa community groups came and integrated with the local land for hundreds of years. 
The Dayak ethnic group is believed to be the indigenous ethnic group who inhabits the island of Borneo. Ramadhan (2017) in his research states that the Dayak ethnic group is a native who inhabits the island of Borneo who has not received a touch of foreign religion or outside influence. The Dayak and Malay ethnicities are the two dominant ethnicities with religion as a dividing line. La Ode in Ramadhan (2017) mentions the Dayak and Malay ethnicities as indigenous ethnicities in West Kalimantan. Another ethnic group that inhabits quite a lot of West Kalimantan is Tionghoa. The largest arrival of Tionghoa ethnic groups in West Kalimantan occurred in the 17th century, where they were brought in by the Sambas Kingdom to become gold mine workers in Bodok (now in Sanggau Regency) and Monterado (Bengkayang Regency).

Table 4. Meaning of conflict style in video as Icons

\begin{tabular}{lcl}
\hline Video Duration & Conflict Style & \multicolumn{1}{c}{ Scenes } \\
\hline $01.19-02.50$ & DO & $\begin{array}{l}\text { The use of red clothes represents the identity of the man in } \\
\text { red as ethnic Tionghoa. }\end{array}$ \\
\hline $02.51-03.43$ & DO & $\begin{array}{l}\text { The headband used by the Dayak ethnic men is an } \\
\text { accessory of the weaving that is commonly worn by the } \\
\text { Dayak ethnic community. }\end{array}$ \\
\hline $03.44-04.22$ & IN & $\begin{array}{l}\text { Emphasize the meaning and application of Bhinneka } \\
\text { Tunggal Ika with the song "Tanah Airku" at the end of the } \\
\text { video by presenting the reading "Bhinneka Tunggal Ika" }\end{array}$ \\
\hline
\end{tabular}

Table 4 shows the meaning of the use of attributes in the video, such as clothing and accessories, which are shown to indicate certain ethnic identities. So that we can see the meaning of the use of each of these attributes in the daily life of the inter-Tionghoa, Dayak, and Malay ethnic communities depicted in this video.

From 01.19 to 02.50 minutes, the wearing of red clothes by the men with glasses represents the identity of the men in red as ethnic Tionghoa. Oppier in Christina (2016) said that red is the color chosen by the Tionghoa community. This color is taken from an important element, namely fire. So that we often find decorations, hangers, and ornaments in Tionghoa people's homes which are dominated by red.

This is reinforced by the statement of Hasanah et al (2014) which defines that red clothes in Tionghoa society, for example at Chinese New Year celebrations, symbolize joy, happiness and success and hope to avoid disaster and crime.

In the Good News From Indonesia website (Destiana, 2019), It is also said that "The clothes they wear also have their own charm, such as the Dayak tribe with their unique traditional clothes, the Melayu with traditional clothes that have striking colors, and the Tionghoa people with red cheongsam and lantern and fan accessories."

Furthermore, at 02.51 to 03.43 minutes, one of the characteristic attributes often used by the Dayak ethnic group can be seen. The headband used by the man is an accessory of the weaving that is commonly worn by the Dayak ethnic community. Even the Sintang City Dayak tie weaving has been registered as an Indonesian Intangible Cultural Heritage (WBTB) Number since 2015 (Kementerian Pendidikan dan Kebudayaan, 2017).

Another icon in this video is at the end of the video at $03.44-04.22$ minutes which shows the emphasis on the meaning and application of 
"Bhinneka Tunggal Ika" - through a song with the title Tanah Airku at the end of the video along with the display of the reading "Bhinneka Tunggal Ika". Represents how the three ethnic groups can accept differences and live side by side with each other.

Table 5. Meaning of conflict style in video as Symbol

\begin{tabular}{lcl}
\hline Video Duration & Conflict Style & \multicolumn{1}{c}{ Scenes } \\
\hline $01.19-01.25$ & DO & $\begin{array}{l}\text { The ethnic Malay man denied that coffee was a more } \\
\text { delicious drink than iced milk. }\end{array}$ \\
\hline $01.26-01.38$ & DO & $\begin{array}{l}\text { Ice is a drink that releases thirst in the afternoon that is } \\
\text { usually drunk on a daily basis. }\end{array}$ \\
\hline $01.39-02.11$ & AV \& DO & $\begin{array}{l}\text { The role of women is believed to bring peace, coolness and } \\
\text { tranquility. }\end{array}$ \\
\hline $02.11-02.50$ & DO & $\begin{array}{l}\text { Chai kwe and bingke are one of the specialties of West } \\
\text { Kalimantan, especially Pontianak which have become daily } \\
\text { food by the people of the city. }\end{array}$ \\
\hline $02.51-03.28$ & DO & $\begin{array}{l}\text { The Dayak ethnic headband becomes the social identity of } \\
\text { the Dayak ethnic group. }\end{array}$ \\
\hline $03.29-04.22$ & DO \& IN & $\begin{array}{l}\text { The ethnic Tionghoa man and the ethnic Dayak man } \\
\text { pointed at each other and stared at each other with } \\
\text { emotional eyes. The ethnic Malay man stared at the two of } \\
\text { them. It represents emotions shown through hand } \\
\text { reactions and eye gestures. }\end{array}$ \\
\hline
\end{tabular}

Table 5 explains how there are symbols that are implied in each scene that can be observed from various points of view such as typical food or drink, accessories and attributes used to body gestures that show the response of each ethnicity in dealing with conflicts and maintaining their respective faces. culture. Men of ethnic Malay refuse that coffee is a more delicious drink and can provide encouragement to be consumed in the afternoon at $01.19-01.25$ minutes.

The next symbol that appears on the minutes $01.26-01.38$ is a statement from an ethnic Malay man that ice can provide more freshness in the afternoon and this is commonly done in everyday life. The ethnic Malay man denied that coffee was a more delicious drink than iced milk. Whereas in Malay culture, there is a Kemponan tradition which is a tradition of appreciating and appreciating food and drinks given by others and coffee is considered the main drink served in everyday life and is the pride of the Pontianak Malay community (Asyura, 2019).

Ice is a drink that releases thirst in the afternoon that is usually drunk on a daily basis. Some types of ice drinks that are commonly drunk by the people of West Kalimantan, one of which is Pontianak City, is ce hun tiao, aloe vera ice, orange ice, and also milk ice as stated by the website Brilio.net (2018).

After going through a difference of opinion, there was a woman who was then seen as a carrier of peace, coolness and serenity because she was a woman. However, at the minute $02.11-02.50$ there is something else that is contradicted and there is a symbol in it, namely typical Tionghoa and Malay ethnic foods. These two foods are typical foods from West Kalimantan, especially Pontianak and have become daily meals by the people of the city.

Chai kwe and bingke are one of the specialties of West Kalimantan, especially Pontianak which have become daily food by the people of the city. 
Chai kwe or another name choi pan is a traditional West Kalimantan cake made from rice flour and sago flour in a semicircular shape like a pastel and white with a skin made from a mixture of rice flour and sago or tapioca then filled with bengkoang, shrimp, fish., chicken, bamboo shoots, or chives. Chai kwe is made by steaming and is a type of dimsum food from mainland China (Exsanti, 2019).

The role of women is believed to be able to bring peace, coolness and tranquility. Retno, Minister of Foreign Affairs of the Republic of Indonesia in the event "Regional Training on Women, Peace and Security" (2019) explained that women have one implicit difference from men, namely maternal instinct. With this instinct, women can create tranquility, peace with a sense of love and care and harmony (Intan, 2019). Furthermore, there is also a Dayak ethnic headband symbol which becomes their social identity at $02.51-03.28$ minutes. The Dayak ethnic headband becomes the social identity of the Dayak ethnic group who view the headband as part of their identity as in the journal "The Meaning of Dayak Sintang Weaving Ikat Viewed From Theo Van Leeuwen Social Semiotic Theory" written by Januarti \& Wempi (2019).

Dayak tie weaving is also considered an ancestral heritage and is even used as a luxurious outfit for parties and other traditional activities (Susilawati, 2017). The final scene in this video is when the three men with different ethnic backgrounds point at each other and give each other sharp gaze which shows they are in an emotional state and this is also supported by the reaction of the hands and eyes.

The ethnic Tionghoa man and the ethnic Malay man pointed at each other and stared at each other with emotional eyes. The Dayak ethnic man was hooked and stared at the two of them with sharp eyes. It represents emotions shown through hand reactions and eye gestures. Body language used by a person can represent the reaction of the emotions that are being felt (Pandhini, 2017).

Table 6. Meaning of conflict style in video as Name

\begin{tabular}{|c|c|c|}
\hline Video Duration & Conflict Style & Scenes \\
\hline $01.19-02.50$ & $\mathrm{DO}$ & $\begin{array}{l}\text { Melayu seem to feel dominant and feel like the hosts in } \\
\text { the area }\end{array}$ \\
\hline $02.51-03.28$ & DO & $\begin{array}{l}\text { The Dayak ethnic man feels dominant and is an } \\
\text { indigenous tribe on the island of Borneo by stating that } \\
\text { tuak already existed in the area even before the Tionghoa } \\
\text { and Melayu ethnic existed in the area. }\end{array}$ \\
\hline $03.29-03.43$ & $\mathrm{DO}$ & $\begin{array}{l}\text { The ethnic Tionghoa man rejected statements made by the } \\
\text { Dayak and Melayu ethnic and stated that they both } \\
\text { misread history. This is done to defend the opinion that he } \\
\text { has expressed before. }\end{array}$ \\
\hline $03.44-04.22$ & DO \& IN & $\begin{array}{l}\text { Men of ethnic Tionghoa, ethnic Dayak men and ethnic } \\
\text { Malay men mingled into Tidayu and were even crowned a } \\
\text { Tolerant City in Singkawang City in } 2018 \text { by the Setara } \\
\text { Institute. }\end{array}$ \\
\hline
\end{tabular}

Table 6 explains how the three ethnic groups argued with each other about who used to be present and lived on the island of Borneo, in general the three ethnic groups also showed each other dominant attitudes to defend their respective statements. 
From 01.19 to 02.50 minutes, two men are seen arguing about which ethnicity was present in the area first and the Melayu ethnic man in this scene looks more dominant and feels that his ethnicity is the host in the area. The dominant attitude possessed by Melayu ethnic can be seen with a high level of enthusiasm for being involved in the world of politics as written in Zakiyah (2017) a book entitled "Prejudice Between Ethnic Groups in West Kalimantan" that Melayu ethnic are considered lazy and dominate in politics.

However, it can be seen that from 02.51 to 03.28 minutes, the Dayak ethnic man conveyed several facts including that one of the uses of tuak is as part of the Dayak ethnic customary event that had been carried out long before the Tionghoa and Malay ethnicities came to the land of Kalimantan. The Dayak ethnic group feels dominant and is an indigenous tribe on the island of Borneo by stating that tuak already existed in the area even before the Tionghoa and Malay ethnic groups existed in the area.

Tuak is a drink substitute for tea or coffee for the Dayak ethnic community which is used as a treat when guests come to visit the cubicles (betang houses) and also as body warmers. This drink is an Indonesian alcoholic drink which is the result of fermentation from sap, rice, or drinks containing sugar (Wedyawati \& Lisa, 2019).

Hearing statements from Melayu and Dayak men who stated that their ethnicity was first present and lived on the island of Borneo, the ethnic Tionghoa men immediately denied the statements of the two at $03.29-03.43$ minutes and said that they had misread history. This is done to maintain the identity or face and opinions that have been shown previously.

Haitama et al. (cited in Zakiyah, 2017) reinforce this assumption in the book "Prejudice between ethnic groups in West Kalimantan" by stating that ethnic Tionghoa are considered to justify any means to achieve their goals. Until in the end, the three ethnic Tionghoa, Dayak and Malay men integrated and mingled into the Tidayu ethnic group who took part until the city of Singkawang was named the Most Tolerant City in 2018 by the Setara Institute (Merry \& Rianto, 2020).

\section{CONCLUSION}

Ethnic Tionghoa, ethnic Dayak, and ethnic Malay have lived side by side with each other in West Kalimantan, one of which is in Pontianak City and Singkawang City. Living side by side in differences saves history and time that is not short to achieve intercultural tolerance and harmony by upholding the motto of "Bhinneka Tunggal Ika". The ethnic Tionghoa in the video represent Tionghoa ethnic conflict styles that avoid saving one's own face and the faces of others and dominate in resolving conflicts. The Malay ethnicity in this video represents the nature of domination which is shown by being confident and not willing to give in to other ethnic groups. Meanwhile, the ethnic Malay also has a style of domination of conflict over other people who he feels does not agree with him. The dominant attitude of the Dayak and Melayu ethnic is based on the history of the two ethnic groups who are considered to be indigenous in West Kalimantan. Even though they are prone to conflict, the spirit of unity of the three ethnic groups is combined in a harmonization based on the tolerance of each ethnicity. "Bhinneka Tunggal Ika" has become the spirit of tolerance and harmonization of the three ethnic groups in 
intercultural communication and conflict management so that divisions can be avoided.

\section{ACKNOWLEDGEMENTS}

Researchers are grateful for the completion of this research thanks to the facilitation of the process of submitting, implementing, and reporting research results, including the publication funding factor which is fully supported by the Department of Research, Development and Community Service (P3M) of Universitas Bunda Mulia.

\section{REFERENCES}

Arnani, M. (2020). Mengapa Orang China Suka Minum Air Panas? Ini Penjelasannya... Kompas.Com.

https://www.kompas.com/tren/read/2020/05/23/140000565/mengapaorang-china-suka-minum-air-panas-ini-penjelasannya-?page $=$ all

Asyura, M. Budaya Kemponan pada Masyarakat Melayu Pontianak (Kajian Kearifan Lokal dalam Kehidupan Sosial Etnik Melayu. Handep, 3(1), 101-120. https://doi.org/10.33652/handep.v3i1.38

Brilio.net. (2018). 7 Minuman khas Pontianak yang bikin dahagamu hilang seketika. https://brilicious.brilio.net/minuman/7-minuman-khas-pontianak-yang-bikindahagamu-hilang-seketika-181130p.html

Christina. (2016). Sebuah Analisis Semiotik Logo Koko Cici Indonesia (Penguatan Identitas Dalam Koko Cici). SEMIOTIKA: Jurnal Komunikasi, 10(2), 241-270. http://dx.doi.org/10.30813/s:jk.v10i2.941

Destiana, M. (2019). Tidayu: Tarian Persatuan Suku di Kalbar. Good News From Indonesia (GNFI). https://www.goodnewsfromindonesia.id/2019/09/03/tidayutarian-persatuan-suku-di-kalbar

Exsanti, Q. C. (2019). Pemanfaatan Daun Kesum dan Ubi Ungu Sebagai Pengganti Daging Pada Kue Choi Pan [Universitas Telkom]. https://openlibrary.telkomuniversity.ac.id/pustaka/files/154700/bab1/pemanf aatan-daun-kesum-dan-ubi-ungu-sebagai-bahan-pengganti-daging-pada-kuechoi-pan.pdf

Fletcher, C. V., Nakazawa, M., Chen, Y. W., Oetzel, J. G., Ting-Toomey, S., Chang, S. J., \& Zhang, Q. (2014). Establishing Cross-Cultural Measurement Equivalence of Scales Associated with Face-Negotiation Theory: A Critical Issue in CrossCultural Comparisons. Journal of International and Intercultural Communication, 7(2), 148-169. https://doi.org/10.1080/17513057.2014.898364

Hasanah, H. (2014). Perayaan Imlek EtnIs Tionghoa: Menakar Implikasi Psikososiologis Perayaan Imlek bagi Komunitas Muslim di Lasem Rembang. Jurnal Penelitian, 8(1), 1-22. http://dx.doi.org/10.21043/jupe.v8i1.1338

Hidayat, D. (2014). Social and Cultural Identity Pendekatan Face Negotation Theory dan Public Relations Multikulturalism Negara Jerman-China dan Indonesia. Jurnal ASPIKOM, 2(2), 115. https://doi.org/10.24329/aspikom.v2i2.64

Intan, G. (2019). Peran Penting Perempuan Tegakkan Perdamaian Dunia. https://www.voaindonesia.com/a/peran-penting-perempuan-tegakkan- 
Edulite Journal of English Education, Literature, and Culture

Vol. 6, No. 2, August 2021, pp. 369-382

E-ISSN: 2528-4479, P-ISSN: 2477-5304

http://jurnal.unissula.ac.id/index.php/edulite DOI: http://dx.doi.org/10.30659/e.6.2.369-382

perdamaian-dunia/4866661.html

Januarti, J., \& Wempi, J. A. (2019). Makna Tenun Ikat Dayak Sintang Ditinjau Dari Teori Semiotika Sosial Theo Van Leeuwen. Bricolage: Jurnal Magister Ilmu Komunikasi, 5(01), 073. https://doi.org/10.30813/bricolage.v5i01.1743

Kementerian Pendidikan dan Kebudayaan. (2017). WARISAN BUDAYA TAK BENDA (WBTB) INDONESIA. Kantor Wakil Republik Indonesia (KWRI) UNESCO. http://kwriu.kemdikbud.go.id/info-budaya-indonesia/warisan-budaya-takbenda-indonesia/

Merry, \& Rianto. (2020). Potensi Perhelatan Budaya Cap Go Meh Sebagai Salah Satu Daya Tarik Wisata di Indonesia (Studi Kasus Perhelatan Budaya Cap Go Meh di Kota Singkawang). Jurnal Hospitality Dan Pariwisata, 6, 1-55. https://journal.ubm.ac.id/index.php/hospitalitypariwisata/article/view/2031/1661

Moningka, C., Owena, A., \& Herlita. (2020). Adaptasi Skala Identitas Etnis: Studi Pada Etnis Jawa dan Etnis Tionghoa di Indonesia. Prosiding Seminar Nasional Pakar Ke 3, 6. file:///C:/Users/user/Downloads/6919-20427-1-SM.pdf

Moriizumi, S., \& Takai, J. (2013). Face Concerns in Interpersonal Conflict: Elaborating on Face Negotiation Theory. The Japanese Journal of Language in Society, 15(2), 46-57. https://doi.org/10.19024/jajls.15.2_46

Muslim. (2016). Varian-Varian Paradigma, Pendekatan, Metode, dan Jenis Penelitian dalam Ilmu Komunikasi. Wahana, 1, No.10(10), 77-85. https://journal.unpak.ac.id/index.php/wahana/article/view/654

Oetzel, J. G., \& Ting-Toomey, S. (2003). Face Concerns in Interpersonal Conflict: A Cross-Cultural Empirical Test of the Face Negotiation Theory. Communication Research, 30(6), 599-624. https://doi.org/10.1177/0093650203257841

Pandhini, A. (2017). Pengembangan Automatic Emotional Regulation Berbasis Buku Panduan Pintar Mengolah Emosi Untuk Menciptakan Komunikasi Efektif Seorang Remaja Dalam Keluarga [Universitas Islam Negeri Sunan Ampel Surabaya]. http://digilib.uinsby.ac.id/15065/4/Bab 2.pdf

Ramadhan, D. (2017). UPAYA DOMINASI ORANG DAYAK: Politik Identitas dalam Dinamika Politik Lokal di Kalimantan Barat. https://populicenter.org/upayadominasi-orang-dayak-politik-identitas-dalam-dinamika-politik-lokal-dikalimantan-barat/

Sari, E. N., \& Samsuri, S. (2020). Etnosentrisme dan Sikap Intoleran Pendatang Terhadap Orang Papua. Jurnal Antropologi: Isu-Isu Sosial Budaya, 22(1), 142. https://doi.org/10.25077/jantro.v22.n1.p142-150.2020

Suprapto, W. (2018). Relokasi masyarakat Madura di Singkawang sebagai bagian dari proses resolusi pasca konflik etnisitas di Kabupaten Sambas. Jurnal PIPSI (Jurnal Pendidikan IPS Indonesia), 3(2), 33-40. https://dx.doi.org/10.26737/jpipsi.v3i2.975

Susilawati, D. (2017). Tenun Ikat Dayak, Warisan Leluhur Penuh Makna. Republika.Co.Id. $\quad$ https://www.republika.co.id/berita/gayahidup/trend/oy9nat328/tenun-ikat-dayak-warisan-leluhur-penuh-makna

Sya, M., Marta, R. F., \& Sadono, T. P. (2019). Tinjauan Historitas Simbol Harmonisasi Antaretnis Tionghoa dan Melayu di Bangka Belitung. Jurnal Sejarah Citra Lekha, 4(2), 153-168. https://doi.org/10.14710/jscl.v4i2.23517

Walsh, S. L., Gregory, E., Lake, Y., \& Gunawardena, C. N. (2003). Self-construal, 
facework, and conflict styles among cultures in online learning environments. Educational Technology Research and Development, 113-122. https://www.jstor.org/stable/30221188

Wedyawati, N., \& Lisa, Y. (2019). Peningkatan Rasa Kesadaran Bahaya Minuman Keras dengan Pendekatan Eksperimen Melalui PPL-KKM di SDN 11 Bora Desa Kecamatan Sayan Kabupaten Melawi. Jurnal Pengabdian Masyarakat Khatulistiwa, 2(1), 17-25. https://doi.org/10.31932/jpmk.v2i1.425

Zakiyah, Z. (2017). Cendekiawan Muslim dan Wacana Konflik Etnis Di Kalimantan Barat. Panangkaran: Jurnal Penelitian Agama dan Masyarakat, 1(2), 191-214. https://doi.org/10.14421/panangkaran.2017.0102-01

Conflict of Interest Statement: The authors declare that the research was conducted in the absence of any commercial or financial relationships that could be construed as a potential conflict of interest.

Copyright (C) 2021 Marta, Merry, Kurniawan, Seftira, and Amanda. This is an open-access article distributed under the terms of the Creative Commons Attribution License (CC BY). The use, distribution or reproduction in other forums is permitted, provided the original author(s) and the copyright owner(s) are credited and that the original publication in this journal is cited, in accordance with accepted academic practice. No use, distribution or reproduction is permitted which does not comply with these terms. 